\title{
SYNERGY OF OPERATIONAL-SEARCHACTIVITIE AND PRE-TRIAL INVESTIGATION
}

\section{Podobnyi O. O.}

\section{INTRODUCTION}

In legal science, it is generally recognized that criminal procedural legislation is an important element of the legal and organizational foundations of operative-investigate activities (hereinafter referred to as OSA). Problems of correlation of criminal procedural and operativeinvestigative legislation were investigated in the works of V. K. Antonov, A. M. Bandurka, V. P. Bakhin, D. I. Bedniakov, R. S. Belkin, M. P. Vodko, V. I. Halagan, V. V. Gevko, M. A. Gromov, Y. M. Groshovy, E. O. Didorenko, A. F. Dolzhenkov, G. O. Dusheyko, E. A. Doly, V. I. Zazytskyy, V. M. Zaykovsky, V. S. Zelenetsky, V. K. Znikin, A. V. Ishchenko, I. P. Kozachenko, V. A. Kolesnik, Ya. Y. Kondratiev, V. S. Kuzmichov, V. A. Lukashov, E. D. Lukyanchikov, M. A. Pogoretsky, M. P. Polyakov, V. L. Regulsky, B. G. RoseVskogo, M. V. Saltyevsky, V. G. Samoilov, O. P. Snigirev, S. M. Stakhovsky, V. M. Tertyshnik, S. A. Schaefer, M. E. Shumilo, O. Yu. Shumilov and others.

In the 1980s, Professor V. G. Samoilov wrote about the need to improve the criminal procedural legislation in order to ensure the effectiveness of the criminal justice system in the fight against criminal crime. In addition to requiring the detection of the crime and the perpetrators by means of operative-investigative measures (hereinafter - OSM), he proposed to supplement the criminal procedural legislation with the provisions on the duty of the body of inquiry to work on the discovery of factual data contributing to the investigation of the subject of evidence and to establish the truth of the case, that is, to solve the problems of criminal justice ${ }^{1}$.

In this connection, it is necessary to give the point of view of V. A. Lukashov, who emphasized that the inextricable link between the operative-search and procedural activity is determined by: a) the unity of tasks of the operative-investigative and procedural activity (detection, prevention, termination and investigation of crimes ); b) a direct indication in the procedural legislation of the duty of the bodies of the inquiry to carry out the necessary OSA for the detection of crimes and the perpetrators of

1 Самойлов В. Г. Документирование по делам оперативной разработки : учеб. пособие. Горький: Горьковская ВШ МВД СССР, 1978. С. 9-11. 
them, with the aim of preventing and stopping the crimes; c) OSA focus on information support of criminal procedure activities of the bodies of inquiry, pre-trial investigation and judicial authorities; d) the criminal-procedural nature of the grounds for carrying out an OSA; e) established by the law on investigative law the right of judges to authorize the implementation of investigative measures related to the restriction of citizens' rights; f) establishing in the operational-search legislation the procedure for using the results of OSA for the preparation and carrying out of investigative and judicial actions; g) the legislative institution of judicial control over the observance of human and citizen's rights and freedoms in the conduct of OSA; h) the legislative body of prosecutorial supervision and departmental control over the accurate and steady implementation of laws by bodies and officials in carrying out $\mathrm{OSA}^{2}$.

\section{The ratio of operative-investigate and criminal-processual activity}

The tasks of criminal justice and OSA as functions of criminal justice, the objective connection of criminal-procedural and operative-investigative activity are conditioned by the following regularities: 1) operativeinvestigative and criminal-procedural activity is carried out only in connection with violation of norms of criminal law, they are two forms of implementation of the criminal law; 2) the unifying link is criminal law, which is why operational investigative and criminal proceedings have basically common goals and objectives.

Summarizing the available points of view, M. P. Vodko formulated the provisions that stipulate the commonality of OSA and criminal proceedings: first, he and other activities are state-legal means of purposefully protecting the rights and interests of man and society from criminal encroachment; secondly, the OSA largely borrows in the criminal process a procedural form to establish its own operative-investigative proceedings at a silent level; third, the fact that some provisions of the OSA are contained in the criminal procedure law; fourth, the commonality of both types of state-legal activity, which is the unity of their purpose, purpose and objectives ${ }^{3}$. At the same time, the scientist concludes that criminal procedural norms remain a benchmark, paramount with respect to OSA. The correlation of OSA and criminal process can take the form of dependence of the results of OSA on criminal procedural procedures, which provide access to search and

\footnotetext{
2 Лукашов В. А. Проблемы оперативно-розыскной деятельности. Москва: ВНИИ МВД России, 2000. С. 11-12.

3 Водько Н. П. Федеральный закон “Об оперативно-розыскной деятельности” в системе Российского законодательства: проблемы и решения: монография. Москва: Издательский дом Шумиловой И. И., 2007. С. 61.
} 
intelligence information in the criminal procedural sphere. On the contrary, the efficiency and quality of OSA are adequately reflected in the outcome of the proceedings.

Among the Ukrainian scientists who researched this problem at the monographic level, it is necessary to note, first of all, the achievements of Professor M. A. Pogoretsky, who, due to its genesis in domestic practice, on the basis of the analysis of foreign experience, as well as by investigating the relationship between operational and search activities and criminal activity. process as activity systems, defining the unity of their epistemological nature and the relationship of legal relations in these areas of law enforcement activities, revealed the functional purpose of the OSA in the criminal process ${ }^{4}$. In particular, they have been shown that the interrelationship between OSA and criminal proceedings is the relation of their dependence on each other, which is manifested in the object of their direction, in the purpose and tasks, the means of implementation, in the interaction of their subjects and the results obtained. Each of these activities is a coherent socio-legal entity, which naturally has its own individual internal structure that specifies the general structure inherent in any activity. In the practical work of OSA, the criminal process is, as a rule, a prerequisite for one another to investigate crimes. Operational search activity also performs the information and support function of the criminal process. The epistemological unity of OSA and the criminal process lies in the fact that they are directed to the knowledge of crime through its traces, which is its result, the process of cognition of which is carried out according to the general laws of epistemology through universal methods of cognition, the application of which in each of these activities has its specificity. OSA is one of the means of criminal procedural cognition that enhances the cognitive capacity of the latter.

It should be noted that at the time of substantiation of this thesis, the connection between the operative-search and criminal-procedural legislation was most clearly reflected in the provisions of Art. 65 of the CPC of Ukraine (1960), according to which the protocols with the relevant annexes, drawn up by the authorized bodies according to the results of the OSA, were recognized. A similar law at that time was contained in Part 2 of Art. 8 of the Law "On OSA", which stated that the results of such OSA such as tacit penetration into the dwelling or other possession of a person, removal of information from communication channels, control of correspondence, telephone conversations, telegraph and other correspondence, the use of other technical means the receipt of information, which is decided by the

\footnotetext{
${ }^{4}$ Погорецький $\quad$ M. А. Функціональне призначення оперативно-розшукової діяльності у кримінальному процесі : монографія. Харків: Арсіс, ЛТД, 2007. 576 с.
} 
court, is drawn up with a protocol with appropriate annexes, which is to be used as a source of evidence in criminal proceedings. However, notwithstanding the progressive provisions of the Law on OSA and the CPC of Ukraine (1960), the requirements that must be laid down in the protocol on conducting an operative-search measure, and that must be properly understood by the relevant annexes to such protocols, specified. Based on this legal situation, two possible directions for further harmonization of the operative-search and criminal-procedural legislation were quite logical. One of these areas envisaged fixing the requirements for the protocol in the operational-search legislation. Proponents of the other - suggested the introduction of amendments to the legal rules of the CPC of Ukraine (1960) on the legislative regulation of the content and requirements of the said protocol ${ }^{5}$.

In this legal situation, we maintained the following view: given that the CPC of Ukraine (1960) in Art. 65 gave the operative units the right to carry out RBMs, and the Law "On OSA" lists them in Art. 8 did not contain, but only formulated as the rights of the operational units, offered to consolidate in the operative-search law the list and concepts of all OSA, to determine which of them should be formalized by the protocol, and to prescribe requirements for the protocol and the relevant annexes thereto ${ }^{6}$.

Another approach was the idea implemented in the new CPC of Ukraine in the development of legal ideas declared by the Criminal Justice Reform Concept of Ukraine. The last document set out the task of creating a new system of pre-trial investigation with the transformation of the current one from a mechanism of persecution and repression into an institute of protection and restoration of violated human rights, introduction of new standards of activity of the criminal justice system, elimination of duplication, streamlining of functions and creation of a new system of law enforcement. The idea ofthe CCP was to revolutionize the main part of the operative-search activity in the criminal-procedural relations.

It should be noted that the implementation of this legal idea in the criminal procedural legislation, Ukraine actually implemented the concept of "proactive" investigation and for the first time in its history introduced the OSA as an integral element in criminal justice.

The concept of "proactive" investigation is being applied by US police and some Western countries. The model of the pre-trial investigation of

${ }^{5}$ Грошевий Ю., Дідоренко Е., Розовський Б. Кримінально-процесуальні аспекти оперативно-розшукової діяльності. Право України. 2003. № 1. С. 73-78.

${ }^{6}$ Подобний О. О. Кримінально-процесуальні основи оперативно-розшукової діяльності органів внутрішніх справ України. Південноукраӥнський правничий часопис. 2010. № 2. C. 47-50. 
undercover, conspiracy-related criminal activity there includes the following elements: b) the stage of operative-investigative investigation, when conducting preliminary inquiry, full investigation, intelligence investigation involves the use of methods constituting both OSAand investigative (criminal-procedural) actions, ie the so-called "intrusive" methods of investigation.

Ukraine has already implemented a number of recommendations of the United Nations Convention Against Transnational Organized Crime before its adoption in 2012 (2012), in particular with respect to such "special investigative methods" provided for in Art. 20 as controlled delivery, "electronic surveillance or other forms of surveillance", "agent operations". It has been implemented in national legislation and a number of other recommendations of the Convention on the Protection of Witnesses (Article 24), mutual legal assistance (Article 18), criminalization of such phenomena as participation in an organized crime group (Article 5), and the laundering of proceeds of crime (Art. 6), corruption (Article 8), etc.

This approach to the improvement of national legislation, based on the recommendations of international legal instruments ratified by Ukraine, was considered acceptable and effective by scientists. At the same time, they warned against the mechanical transfer of models of foreign legal systems to the domestic realities. Scientists in the field of criminal proceedings have noted that the norms of the use of OSA materials in the criminal process of foreign countries are in other models (types) of the criminal process, each of which for centuries has produced its own "restraints" and "balances", which are harmoniously interwoven in all stages of the judiciary taking into account its form, principles, legal status of subjects, etc. These models, including the institute for the use of intelligence and search information in the criminal process of each of the studied countries, have their disadvantages, which are criticized in scientific and practical sources of foreign countries. In view of the above, as well as national traditions, the level of scientific development of this problem, the corruption of the domestic law enforcement and judicial bodies, the mentality, the economic conditions in which our country is located, the level of crime, as well as the state of scientific development of the legal reform of Ukraine, expressed the view that none of the foreign countries can be an ideal model for us today. Therefore, scientists have emphasized that the mechanical transfer to the domestic criminal procedural legislation of the norms of any institute of these countries without coordination with the respective legal institutions of the domestic legislation and their separate norms and taking into account 
domestic realities can lead to imbalance: or weakening of human rights measures., or to reduce the effectiveness of the fight against crime ${ }^{7}$.

Unfortunately, at this time we have to state that the above forecast of the situation development was justified, and in the second direction - to the greatest extent.

At the present stage of development of Ukraine, criminality activates unlawful activity, and criminal policy and the state at a critical level cannot cope with it. The current criminal situation requires adjustments to the policy of countering criminal offenses ${ }^{8}$.

Today, Chapter 21 of Section III of the current CPC of Ukraine is entitled "Covert investigative (detective) actions" (hereinafter - CI(D)A) and provides for their classification into two main groups. The first group is organized in $\S 2$, which is entitled "Interference with Private Communication". The unspoken investigative actions of the aforementioned group include: audio and video control of a person (Article 260); arrest of correspondence (Article 261); review and withdrawal of correspondence (Article 262); removal of information from transport telecommunications networks (Article 263); removal of information from electronic information systems (Article 264); the recording and storage of information obtained from telecommunications networks by technical means and as a result of the removal of information from electronic information systems (265); study of information obtained from the application of technical means (266). The second group is regulated by $\S 3$, entitled "Other types of unspoken investigative (investigative) actions" and combines the following types: survey of publicly inaccessible places, housing or other possession of a person (Article 267); establishing the location of a radio electronic device (Article 268); observation of a person, thing or place (p. 269); monitoring of bank accounts (Article 269-1); audio-video control of the place (Art. 270); control over the commission of a crime (Article 271); performing a specific task of disclosing the criminal activity of an organized group or criminal organization (Article 272); the means used in conducting unspoken investigative (search) actions (Article 273); unspoken receipt of samples required for comparative study (Article 274) the use of confidential cooperation (Article 275).

At the same time, in Part 1 of Art. 256 of the CPC of Ukraine (2012) "Use of results of unspoken investigative (investigative) actions in evidence"

7 Погорецький М. А.Функціональне призначення оперативно-розшукової діяльності у кримінальному процесі : монографія. Харків: Арсіс, ЛТД, 2007. С. 148.

8 Водько Н. П. Формирование политики противодействия уголовным правонарушениям в Украине (оперативно-розыскной аспект) : монография. Одесса : Фенікс, 2015. C. 561. 
states that protocols on conducting of unspoken investigative (investigative) actions, audio or video recordings, photographs, other results obtained through the use of technical means, seized items and documents or copies thereof during their conduct may be used in proving on the same grounds as the results of other investigative (investigative) actions during the pre-trial investigation. Part 2 of the said article states that persons who conducted the CI(D)A or were involved in their conduct may be questioned as witnesses. The interrogation of these persons may be conducted with the secrecy of the information about these persons and with the application of the relevant security measures prescribed by law. Finally, Part 3 establishes a law according to which, in the case of use to prove the results of unspoken investigative (search) actions, the persons whose actions or contacts were carried out may be questioned. Such persons shall be notified of conducting unspoken investigative (search) actions only against them within the period stipulated by Art. 253 of this Code, and to the extent that it affects their rights, freedoms or interests.

These CI(D)A, which in fact previously corresponded to similar OSA, are implemented after criminal proceedings have commenced. The subjects of their conduct of the CPC of Ukraine in 2012 have appointed an investigator and a prosecutor, and the examination of the petitions and the approval of the permission for these actions is carried out by the investigating judge. According to Art. 41 of the CPC of Ukraine operational units carry out both investigative (investigative) actions and CI(D)Ain criminal proceedings on the written order of the investigator, the prosecutor. During the execution of the investigator's instructions, the prosecutor employees of the operational unit use the powers of the investigator. Employees of operational units are not allowed to conduct criminal proceedings on their own initiative or to apply to the investigating judge or prosecutor. The orders of the investigator, the prosecutor to carry out investigative (search) actions and unspoken investigative (search) actions are mandatory for the execution of operational units.

Regarding the previously raised question about the use of the results of OSA (materials on illegal activity collected before the start of criminal proceedings) in the criminal process, the answer is provided by Part 2 of Art. 99 of the CPC of Ukraine "Documents", which states that the materials, which record factual data on illegal activities of individuals and groups of persons, collected by operational units in compliance with the requirements of the Law on OSA, are documents and can be used in criminal proceedings as evidence.

The above-mentioned opinions of scientists and the provisions of modern legislation give reason to claim that in the conditions of legislative 
consolidation of the legal structure of the maximum combination of operative-investigative and criminal-procedural types of activity, nevertheless, these state-legal functions remain integral social and legal entities having their individual internal structure. In practical terms, on the basis of the tasks and grounds for conducting it, the OSA will continue to be a prerequisite for criminal proceedings in the investigation of crimes, and will therefore serve as an information and support function of the criminal process. At the same time, joining the structure of the CPC of Ukraine Chapter 21 "Unofficial Investigative (Investigative) Actions" in fact provided for a procedure of investigating crimes in an unofficial form and significantly expanded the cognitive capabilities of the criminal process through the tools of OSA, which will continue to be objectively qualified by the operative division. At the same time, the proposal to consolidate an unspoken investigation into the CPC of Ukraine as an independent form of pre-trial investigation was first introduced by Professor M. P. Vodko'.

These theoretical provisions allow us to draw some preliminary conclusions about the ratio of operative-investigative and criminalprocedural activities in the current conditions of criminal justice reform. Their common features are: the focus of criminal-procedural and operational-search activities on the protection of human rights and interests; unity of the ultimate tasks of operative-investigative and criminal-procedural law enforcement functions; criminal-procedural regulation of the legal status of operational units and investigative bodies; the focus of operational investigative measures and investigative actions on information and procedural support of criminal justice; unity of guarantees of lawfulness of carrying out unspoken actions in OSA and criminal process. At the same time, the distinctive features of these activities include the independent nature of the legal basis for their functioning, the differences between the beginning and the limits of the proceedings, the subordination of criminal investigative activity to the purpose of the operative-search activity.

\section{Theoretical and legal issues of OSA}

General theoretical problems of operational development as a separate organizational and tactical form of OSA were laid mainly in the 80's - in the early 90's of the last century in the works of V. G. Bobrov, B. E. Bogdanov, Yu. I. Veselov, A. F. Vozny, E. O. Didorenko, S. S. Ovchinsky and others. Among the Ukrainian scientists who later dealt with this issue in detail, it is

${ }^{9}$ Водько Н. П. О соотношении негласных следственных (розыскных) действий и оперативно-розыскных мероприятий в Украине. Оперативник (сыщик). № 1(34). 20013. C. 6-12. 
necessary to distinguish the achievements of O. M. Bandurka, O. F. Dolzhenkov, I. P. Kozachenko. However, most theoretically, at the level of doctoral dissertation, this problem was investigated by V. G. Bobrov, who justified the operative development as a form of OSA. In particular, it allows concentrated use of the whole arsenal of means and methods, to capture all useful information in the fight against crime and to conspicuously carry out the process of "uncovering" the crimes and the search of the perpetrators. With the help of rapid development, it becomes possible to penetrate the mysteries of criminals, establish the facts and circumstances necessary for their disclosure, obtain information, the generalization of which contributes to a more effective placement of silent employees and improve the operational and search tactics ${ }^{10}$.

Professor V. G. Samoilov defined operational development as the process of carrying out operative-search measures against a person or group of persons who are reasonably suspected of committing crimes, in order to prevent them, if otherwise impossible or difficult to achieve ${ }^{11}$. B. I. Bogdanov substantially supplemented this definition by proposing an approach according to which it is a process of implicit realization of a set of coordinated, interrelated, prepared on the basis of the best practices, achievements of scientific and technological progress and provisions of the science of management of the OSA in relation to a person or group of persons. Who are reasonably suspected of committing unlawful acts, with a view to preventing or "uncovering" crimes, or in relation to criminals who are being hijacked, with a view to finding them when it is impossible or otherwise possible to achieve the intended purpose it is difficult ${ }^{12}$.

Such consideration of the evolution of views on the essence of operational development led to its understanding, which was undoubtedly perceived before the adoption of the CPC of Ukraine in 2012. According to this understanding under operational development was defined as a comprehensive system of authority's carried out by operational units within the established operational investigations (hereinafter - OIC) in respect of a person or group of persons reasonably suspected of preparing or committing crimes for the purpose of preventing or "disclosing" them, as well as in

${ }^{10}$ Бобров В. Г. Правовые и организационные основы оперативной разработки, пути и меры ее совершенствования (вопросы теории и практики): дис. ... д-ра юрид. наук: 21.00.06. Москва: Академия МВД СССР, 1990. С. 3.

${ }^{11}$ Самойлов В. Г. Реализация материалов агентурной разработки : учебное пособие. Минск: МССШМ МВД СССР, 1988. 84 с.

${ }^{12}$ Богданов Б. Е. Организация и тактика оперативной разработки аппаратами БХСС лиц, занимающихся замаскированной преступной деятельностью. М.: Академия МВД CCCP, 1983. C. 4. 
relation to criminals hiding from an investigation, a court or o serving a criminal sentence, searching for and detaining them, or finding the whereabouts of a missing person if these results are not possible or too difficult to achieve otherwise.

In the conditions of today, with the adoption of the CPC of Ukraine (2012) and amending the Law on OSA, there was a maximum convergence of operative-investigative and criminal-procedural law enforcement functions, which led, as we have already noted, to actual implementation in criminal justice. Or in the form of NA (P) D, provided for in Chapter 21 of the said Code. Regarding the problems of operative development, the grounds for carrying out the OSA in accordance with the mentioned legislative changes remained "the availability of sufficient information that needs to be verified by means of operative-investigative measures and means", only "about the crimes being prepared and the persons preparing crimes". Grounds for information on serious and particularly grave crimes committed by unidentified persons, on persons who committed such crimes, if information on crimes and persons who committed them cannot be obtained in another way, in accordance with the provisions of the CPC of Ukraine (2012) automatically stipulate the initiation of a pre-trial investigation, which, at the same time, according to the decision of the investigator, prosecutor, investigating judge, may be carried out by conducting the CI(D)A, the period of which is traditional for the OSA - six months with the possibility of extending up to twelve and eighteen months. The investigator conducting the pre-trial investigation of a crime, or on his behalf - authorized operational units (Article 246) has the right to conduct the CI(D)A. Moreover, the publicity of such an investigation is ensured in accordance with Part 2 of Art. 253 and Art. 254 of the CPC, which in particular provide for the procedure according to which the specific time of notification to a person that he or she has been subjected to CI(D)A is determined taking into account the presence or absence of threats to the goal of pre-trial investigation, public safety, life or health of persons involved in the conduct of the $\mathrm{CI}(\mathrm{D}) \mathrm{A}$. The relevant notification of the fact and the results of the CI(D)A must be made within twelve months from the date of termination of such actions, but not later than in the court of indictment.

Obviously, under such conditions, the almost complete identity of the categories "operative development" and "silent investigation" taking into account the expansion of its subjects, operative development (silent investigation) can be defined as a complex system of OSA and CI(D)A, which is carried out in the conditions of impossibility of reaching its tasks otherwise: (a) by operational units within the established for a person or group of persons who are reasonably suspected of serious or particularly 
serious crime, with a view to preventing or suspending them in relation to suspects (defendants) hiding from the investigation, the court, serving a criminal sentence, for their search and detention, for establishing the whereabouts of the person who disappeared unknowingly; (b) investigators, prosecutors, on their behalf, operational units, in criminal proceedings against a person or group of persons who are reasonably suspected of committing such crimes, as well as to ensure the safety of court and law enforcement officials, persons involved in criminal proceedings judicial proceedings, their families and close relatives, in order to create the necessary conditions for the proper administration of justice ${ }^{13}$. There are a number of conclusions to be drawn from the above legislative provisions, the formulated definition, the analysis of the practice of OSA and the criminal process.

First, operational development as an organizationally-tactical form of OSA and unspoken investigation unites a complex of OSA and CI(D)A aimed at identifying and recording data on the circumstances of preparation, commission and concealment of crimes, on the composition and role functions of participants in criminal activities., their location, the sequence of the crime (s), the means of counteracting the criminal environment to establish the truth in the case, and the like.

Second, the complexity of the use of OSA and CI(D)Adetermines the priority of their combination in the solution of various tactical tasks in order to achieve the possibility at an early stage of the termination of criminal acts, or to gather complete, sufficient information for the investigation of committed or committed crimes.

Third, operational development, as the highest and sufficiently complex organizational and tactical form of OSA, as well as unspoken investigation, contain the entire arsenal of operational and search activities and are not used in the termination and investigation of any crime, but only of those types and forms, which are of high public danger, are complex in nature in their timely detection and full investigation.

Starting from the above, as well as from the views expressed in the specialized literature, it is possible to formulate tasks that are solved in the framework of operational development (unspoken investigation).

Main tasks: 1) prevention or cessation of serious or especially serious crimes that are being prepared; 2) the establishment of all members of the

13 Подобный А. А.О единой концепции оперативной разработки и негласного расследования в условиях реформирования оперативно-розыскного и уголовного процессуального законодательства Украины. Оперативник (сыщщик). № 2(35). 2013. C. $58-61$. 
group, the functions of each; 3) documenting specific facts (episodes) of criminal acts; 4) preventing the possibility of the developed to evade the investigation and the court, to counteract the establishment of truth; 5) ensuring the safety of participants in operational search activities, criminal proceedings, court employees and law enforcement agencies, their relatives.

Other tasks include: identifying ways to engage new members, corrupt relationships, creating your own security system and counteracting the law enforcement system; establishment of the fact of existence of "common law", the system of distribution of criminal proceeds, their legalization; ensuring compensation for material damages caused by the actions of the developers and their accomplices; detention of wanted criminals; identifying and eliminating conditions conducive to crime.

From this list of tasks of operational development and unspoken investigation, it follows that in their content they are aimed at solving in general the problems of criminal justice provided for in Art. 2 of the CPC of Ukraine.

Prompt development and unspoken investigation fulfill the complex function of creating optimal conditions for the effective implementation of criminal procedural evidence at all stages of the investigation of crimes and thus ensure the implementation of the principle of inevitability of punishment for the crime. This approach further confirms the objectivity and validity of the concept of OSA theory, supported in the theory of criminal proceedings ${ }^{14}$, that they are independent state-legal functions of combating crime and together constitute the unity of criminal justice.

In the conditions of the Criminal Procedure Code of Ukraine in 1960, dogmas about proving as an exclusively criminal procedural function adversely affected practical activity. Due to the dispersion of the subjects of the OSA and the criminal process, the principles of completeness and objectivity of the process of proving were often violated, which was mainly realized not because of their combined efforts, but by the weakened capabilities of the investigator. Therefore, prompt development and tacit investigation as a complex form of complex application of OSA and Emergency Situations should be used in cases where it is impossible to suspend or investigate complex, socially dangerous acts solely by means of RIAs and vigorous criminal-procedural actions.

Central to the theoretical and legal issues of rapid development is undoubtedly the general theoretical issues of operational investigative evidence.

14 Погорецький М. А. Функціональне призначення оперативно-розшукової діяльності у кримінальному процесі : монографія. Харків: Арсіс, ЛТД, 2007. С. 269-270. 
The problem of operational-search documentation was and will continue to be central to the practice of ARDs and, accordingly, unspoken investigations. V. G. Bobrov, B. V. Boytsov, V. M. Burikin, A. F. Vozniy, V. I. Medushevsky, V. G. Samoilov, G. K. Sinilov and others have distinguished themselves with the researches of this subject.

As early as the early 1970s, A. F. Voznyi noted that documentation was closely linked to evidence in criminal proceedings, since both the first and the second had the sole purpose of "uncovering" a crime ${ }^{15}$. In this regard, they also note the unity of documentation and evidence, which consists not only in the fact that they use the same cognitive methods, but also in a single cognitive process for them - gathering, fixing, researching, evaluating information, common purpose, adhering to the criterion of belonging, ensuring its authenticity. In fact, search and search information on the content must meet the same requirements as the evidence. Until recently, before the adoption of the CPC of Ukraine in 2012, the difference between them was the means and methods of collecting and investigating information (actual data), as well as the significance of the results obtained.

Unfortunately, the operative-investigative legislation of Ukraine does not specify the term "documentation". Another approach is demonstrated by the legislators of the Russian Federation, who in Art. 10 of the Federal Law "On search operations" define the documentation as the process of collecting and organizing information, checking and evaluating the results of OSA, as well as the adoption of appropriate decisions by the operational search units, based on the materials of operational accounting. In domestic law, the term in question was applied only in the Law of Ukraine "On Information", which specifies that information about a person is a set of documented or publicly disclosed information about a person, and sources of documented information about a person are issued in his name documents signed it documents, as well as information about the person, collected by state and local self-government bodies within the limits of their powers. Obviously, there is a need to consolidate such a central category as "documentation" and in the domestic law "On OSA".

In the theory of OSA, documentation is usually understood to mean: a) the process of knowing, that is, collecting (detecting), studying (checking), assessing and recording in the documents the actual data about the circumstances of the crime; b) activities enabling the use of information obtained by means of search and search in criminal proceedings ${ }^{16}$. Thus,

${ }^{15}$ Возный А. Ф. Основные положения оперативной разработки : обзорная лекция. Киев: КВШ МВД СССР, 1973. С. 26.

16 Теория оперативно-розыскной деятельности : учебник/ [под ред. К. К. Горяинова, В. С. Овчинского, Г. К. Синилова ]. Москва: ИНФРА-М, 2008. С. 422. 
documentation forms the basis of proof in criminal proceedings. In the course of documentary evidence, it performs the function of fixing in the procedural documents information which is then used in the evidence in criminal proceedings. Documentation in OSA is not only intended to capture information obtained from the implementation of OSA. It provides for the process of collecting documented information, verifying, evaluating and using it in solving problems of OSA, regulated by departmental normative acts, and in criminal proceedings - in accordance with the procedure established by the CCP.

Therefore, documentation in the OSA can be considered as a process of reflecting in the official documentation of the actual data obtained as a result of the OSA, as well as a process of cognition that has a specific legal nature and is carried out to solve the tasks of this activity, in particular such a central task as the recording of actual data on unlawful acts of individuals and groups, for which the Criminal Code of Ukraine is responsible. Particularly relevant in this connection is the issue of establishing objective truth in documenting. The content of this category is determined by the circle of all circumstances, the establishment of which ensures the fulfillment of the tasks assigned to the OSA. Due to the knowledge of the occurrence of any crime, including those that are elements of organized crime, the content of objective truth is determined by the range of circumstances to be proven in criminal proceedings.

The Criminal Procedure Code of Ukraine in Art. 91 sets out the following circumstances, which are subject to proving in criminal proceedings: 1) the event of the criminal offense (time, place, method and other circumstances of committing the criminal offense); 2) the guilt of the accused in committing a criminal offense, the form of guilt, motive and purpose of committing the criminal offense; 3 ) the type and amount of the damage caused by the criminal offense, as well as the amount of the procedural costs; 4) circumstances affecting the severity of the criminal offense characterize the person of the accused, aggravate or mitigate punishments which exclude criminal liability or are grounds for closing criminal proceedings; 5) circumstances which are grounds for dismissal from criminal responsibility or punishment; 6) Circumstances confirming that the money, valuables and other property subject to special confiscation were obtained as a result of the criminal offense and / or are the proceeds of such property, or were intended (used) to persuade the person to commit the criminal offense, financing and / or the provision of a criminal offense or compensation for its commission, or is the subject of a criminal offense, including those related to their illicit trafficking, or searched, manufactured, adapted and either used as a means or instrument of a criminal offense; 
7) circumstances that are grounds for applying to legal persons measures of criminal nature.

At the same time, according to experts, in separate methods should be reflected and auxiliary circumstances (evidential facts), typical for this category of crimes, by means of which and through clarification of which the main circumstances of the crime - the subject of proof are established ${ }^{17}$.

Successful discovery and consolidation of factual data by conducting unspoken investigative (investigative) actions is determined, first of all, by compliance with the requirements that put forward for documentation: legality, timeliness, completeness, and confidentiality.

\section{CONCLUSIONS}

Therefore, despite some differences in the individual formulations of documentation, for the time being the specified category is defined as a complex of OSA, mostly silent, aimed at establishing the actual data on the event of the crime and the persons involved in committing it, verifying their accuracy and ensuring their further use. as evidence in criminal proceedings.

In contrast to criminal procedural evidence, documentation in an OSA provides knowledge of both past and present events, as well as those that may occur in the future. At the same time, participants in the ongoing and ongoing processes have the opportunity to directly observe the very fact of the crime, becoming an eyewitness and as a result being questioned as witnesses in criminal proceedings. In this case, direct observation by the participants of the documentation of the investigated event becomes a way of knowing the circumstances of the objective reality. In other cases, the crime is known as an event of the past. Documentation provides knowledge of the event under investigation by recording the actual data reflected in the memory of victims, eyewitnesses, as well as traces left on objects and other material media ${ }^{18}$.

The last thesis is sufficiently developed in the theory of OSA at the level of three main areas of documentation of criminal activity developed: 1) identification of persons who are aware of factual data about criminal activity, and ensuring that they can continue to participate in criminal proceedings as witnesses; 2) unspecified identification of objects, documents, substances that may contain information about illegal activities,

17 Танасевич В. Г. Теоретические основы методики расследования преступлений. Советское государство и право. 1976. № 6 С. 91-92; Стрельцов Е. Л. Обстоятельства, подлежащие доказыванию по делам о корыстно-насильственных преступлениях. Криминалистика и судебная экспертиза. К.: Киев. НИИСЭ, 1995. Вып. 47. С. 67-69.

18 Теория оперативно-розыскной деятельности : учебник/ [под ред. К. К. Горяинова, В. С. Овчинского, Г. К. Синилова ]. Москва: ИНФРА-М, 2008. С. 424. 
and ensuring that they can be used after the start of pre-trial investigation as physical evidence; 3) unspoken fixation of the actions of the developed persons with the use of technical means for the subsequent use of the obtained data in the investigation.

During the documentation of organized criminal activity, operational units and pre-trial investigation bodies have to act in two main operationaltactical situations: firstly, in relation to persons for whom there are data on participation in the preparation of a crime (under the scheme "from person to crime"); secondly, about the unidentified perpetrators of the crime (under the scheme "from crime to person").

Working in these areas in certain tactical situations, operative units and pre-trial investigation bodies, as we have already noted, now use almost a single system of unspoken investigative (investigative) actions.

\section{SUMMARY}

The article deals with the ratio of operative-search and criminalprocedural activity, as well as theoretical and legal aspects of operational development.

It is proved that in terms of legislative consolidation of the legal doctrine of the maximum combination of operative-investigative and criminalprocedural activities, based on the tasks and grounds for implementation, operative-investigative activity remains a prerequisite and becomes a component of the criminal process in the investigation of crimes. Obtaining, within the framework of criminal proceedings, the authority to conduct unspoken investigative (investigative) actions has greatly expanded the latter's cognitive capabilities through the tools of operational and search activities, which will be used by the operational units in a qualified manner.

The concept of unity (synergy) of operational development and unspoken investigation as a complex system of operative-investigative measures and silent investigative (investigative) actions carried out under conditions of impossibility to achieve otherwise the objectives of criminal proceedings and operative-investigative activity is substantiated: (a) by operational units within the framework of a criminal investigation into a person or group of persons who are reasonably suspected of committing serious or particularly serious crimes, with a view to preventing or terminating them, in dnosno suspect (accused) who are fleeing from the investigation, trial, serving criminal punishment for their investigation and detention; (b) investigators, prosecutors, on their behalf, operational units, in criminal proceedings for the purpose of establishing the perpetrators, as well as for a person or group of persons who are reasonably suspected of committing such crimes, to ensure the safety of participants in criminal proceedings and the necessary conditions for proper the administration of justice. 


\section{REFERENCES}

1. Бобров В. Г. Правовые и организационные основы оперативной разработки, пути и меры ее совершенствования (вопросы теории и практики): дис. ... д-ра юрид. наук: 21.00.06. Москва: Академия МВД CCCP, 1990. $286 \mathrm{c}$.

2. Богданов Б. Е. Организация и тактика оперативной разработки аппаратами БХСС лиц, занимающихся замаскированной преступной деятельностью. М.: Академия МВД СССР, 1983. 36 с.

3. Водько Н. П.О соотношении негласных следственных (розыскных) действий и оперативно-розыскных мероприятий в Украине. Оперативник (сыщик). № 1(34). 20013. С. 6-12.

4. Водько Н. П. Федеральный закон "Об оперативно-розыскной деятельности" в системе Российского законодательства: проблемы и решения : монография. Москва: Издательский дом Шумиловой И. И., 2007. $131 \mathrm{c}$.

5. Водько Н. П. Формирование политики противодействия уголовным правонарушениям в Украине (оперативно-розыскной аспект) : монография. Одесса : Фенікс, 2015. 580 с.

6. Возный А. Ф. Основные положения оперативной разработки : обзорная лекция. Киев: КВШ МВД СССР, 1973. 40 с.

7. Грошевий Ю., Дідоренко Е., Розовський Б. Кримінальнопроцесуальні аспекти оперативно-розшукової діяльності. Право України. 2003. № 1. С. 73-78.

8. Лукашов В. А. Проблемы оперативно-розыскной деятельности. Москва: ВНИИ МВД России, 2000. 149 с.

9. Погорецький М. А. Функціональне призначення оперативнорозшукової діяльності у кримінальному процесі : монографія. Харків: Арсіс, ЛТД, 2007. $576 \mathrm{c}$.

10. Подобний О. О.Кримінально-процесуальні основи оперативнорозшукової діяльності органів внутрішніх справ України. Південноукраӥнський правничий часопис. 2010. № 2. С. 47-50.

11. Подобный А. А. О единой концепции оперативной разработки и негласного расследования в условиях реформирования оперативнорозыскного и уголовного процессуального законодательства Украины. Оперативник (сыщик). № 2(35). 2013. С. 58-61.

12. Самойлов В. Г. Документирование по делам оперативной разработки : учеб. пособие. Горький: Горьковская ВШ МВД СССР, 1978. $140 \mathrm{c}$.

13. Самойлов В. Г. Реализация материалов агентурной разработки : учебное пособие. Минск: МССШМ МВД СССР, 1988. 84 с. 
14. Стрельцов Е. Л. Обстоятельства, подлежащие доказыванию по делам о корыстно-насильственных преступлениях. Криминалистика и судебная экспертиза. К.: Киев. НИИСЭ, 1995. Вып. 47. С. 67-69.

15. Танасевич В. Г. Теоретические основы методики расследования преступлений. Советское государство и право. 1976. № 6. С. 91-92.

16. Теория оперативно-розыскной деятельности : учебник / [ под ред. К. К. Горяинова, В. С. Овчинского, Г. К. Синилова ]. Москва: ИНФРА-М, 2008. 832 с.

\section{Information about the author:} Podobnyi O. O., Doctor of Laws, Professor, Head of the Department of Criminal Law, Process and Criminalistics, International Humanities University 33, Fontanska Road str., Odessa, 65009, Ukraine 